DOI https://doi.org/10.18551/rjoas.2017-05.23

\title{
THE INFLUENCES OF LEADERSHIP STYLES, ORGANIZATIONAL COMMUNICATION, AND JOB SATISFACTION TOWARD EMPLOYEES' JOB PERFORMANCE IN DOING CONSTRUCTION JOBS: A STUDY ON THREE CONSTRUCTION COMPANIES IN JAKARTA
}

\author{
Yudiawan Markiz* \\ Doctorate Program of Management Studies, University of Brawijaya, Indonesia \\ Setiawan Margono, Irawanto Dodi Wirawan, Rofiq Ainur \\ Faculty of Economics and Business, University of Brawijaya, Indonesia \\ *E-mail: markizyudiawan.ub@gmail.com
}

\begin{abstract}
This study was conducted to investigate and to analyze the influence of leadership styles, organizational communication and job satisfaction toward workers' performance in doing construction jobs in three different construction companies in Jakarta. The study attempts at explaining causal-effect relationship among the variables of this study through a quantitative approach and positivism paradigm. The population of this study included all employees who were actively involved in the projects of 3 construction companies; PT. Mega Persada Indonesia, PT. Jaya Teknik Indonesia, and PT. Jaga Citra Inti. Those three companies were in the process of completing construction jobs. Hence, those companies were seen to be able to provide information as the data of this study. The samples were determined through quota sampling method in which only certain employees in certain level including the senior staffs or managerial staffs who understood the detail of the projects. Generalized Structured Component Analysis (GSCA) was employed to analyze the data of this study which results show that; (1) leadership styles do not have any significant influence on job satisfaction. (2) Organizational communication has an influence on employees' performance. (3) Leadership styles do not have any significant influence on the construction job performance. (4) Organizational communication has a significant influence on the construction job performance. (5) Job satisfaction has a significant influence on the construction job performance. (6) Job satisfaction is not the mediating variable between leadership styles and construction job performance. (7) Job satisfaction is a mediating variable between the organizational communication and the construction job performance.
\end{abstract}

\section{KEY WORDS}

Leadership styles, organizational communication, job satisfaction, job performance.

The development of construction industries is mainly affected by the economic development. Indonesia has recorded a significant economic growth within the last five years at $5 \%$ to $6 \%$ in each year. This economic growth holds a major role in stimulating the growth of construction industries in Indonesia. The growth of construction industrial market is also followed by the increasing competition among construction companies. Besides facing the era of local autonomy, construction companies are also facing the globalization era marked by the implementation of the Asean Free Trade Area (AFTA) in 2003 and the ASEAN Economic Community in 2016 which allow construction companies from abroad to compete in the national construction market in Indonesia. Construction companies are challenged to stay competitive in this global market (Marboen, 2014). The competitiveness of construction companies relies on the professionalism of the companies. Companies are required to be keen on seeking chances to take for longer-term period. Excellent project management becomes a key point to the success of the construction companies. It is stated in the American Standard Project Management of Body of Knowledge, Palang Merah Indonesia (PMI) there are 9 key factors that should be owned by a project manager including; a) Project 
Integration Management; b) Project Scope Management; c) Project Time Management; d) Project Cost Management; e) Project Quality Management; f) Project Human Resources Management; g) Project Communication Management; h) Project Risk Management; i) Project Procurement Management.

A project manager should possess leadership capabilities besides having good managerial skills. Previous study conducted by Kerzner (2001) showed that leadership styles determine whether or not a person is chosen as a project manager. Leadership within the context of construction industry has a key role as the jobs in the field are quite complex in which various aspects are involved in the project (Hillebrandt, 2000). Besides leadership styles have a great role to the success of a construction company in handling construction jobs, Bjeirmi et al. (2007) highlighted that inefficient communication may also trigger low quality work, financial claim, safety and inefficiency. Good communication is one of interpersonal competences which plays an important role to the success of doing construction jobs. Other studies also showed that a project supervisor should intensively communicate and pass any information to make sure that workers are doing their jobs based on the standards in order to avoid problems. According to the statements of Yang, et al. (2007); Bjeirmi et al. (2007) and; Watson and Gallagher (2005), communication plays an important role to do successful construction jobs that meet certain targets or expectations.

High job satisfaction felt by employees also has a crucial role for an organization to support high quality performance as expected by the organization. Review on the correlation between job satisfaction and job performance is still necessary to conduct in different organization and different job sectors. The high competition among construction companies demands companies to show their high-quality work and achievement. Job satisfaction has been an interesting issue for psychologists to explore. A relationship between job satisfaction and job performance as "holy grail" in psychology industries. Studies on the relationship were done by some researchers including Shore and Martin (1989), Riketta (2008) who found that job satisfaction is strong enough to influence employees' performance. Perera at al. (2014) also stated that job satisfaction has a positive influence toward job performance.

A project manager handles quite strategic roles as the catalyzer and determinant in the exploration of project resources among central offices and project staffs. The success of the project also depends on the quality of the communication maintained among stake holders, besides it is also affected by employees' job satisfaction that supports the improvement of their job performance. Based on those explanation, research questions were formulated as follow.

1. Do leadership styles influence employees' job satisfaction?

2. Does organizational communication influence employees' job satisfaction?

3. Do leadership styles influence the performance of a company in handling construction jobs?

4. Does organizational communication influence the performance of a company in handling construction jobs?

5. Does job satisfaction influence the performance of a company in handling construction jobs?

6. Is job satisfaction a mediating variable between the influence of leadership styles on the performance of a company in handling construction jobs?

7. Is job satisfaction a mediating variable between the influences of organizational communication on the performance of a company in handling construction jobs?

\section{REVIEW OF THE RELATED THEORIES}

Simanjuntak (2005) stated that performance is the achievement of doing certain tasks. Simanjuntak also regarded individual job performance as an achievement to the target given to him/her in a certain period of time. Performance is also the result of doing certain jobs based on certain standards set by the company. Sedarmayanti (2007) mentioned some factors that influence employees' job performance which are; 1) attitude and mentality (motivation, discipline, ethics), 2) education, 3) skills, 4) leadership management, 5) level of 
earning, 6) salary and health, 7) insurance, 8) work environment, 9) facilities, 10) technology, and 11) career path. Construction jobs require lots of people, lengthy process, various steps, and supervision from public sector as well as non-government sector to bring success to a project (Takim and Akintoye, 2002). Measurement on the performance of certain construction project helps a manager to provide continuum feedback during the operational activities (Lehtonen, 2001). Documentation and recording of any data related to the work will also provide great reference in anticipating future problems, claim, maintenance, and renovation of the building (Thomas et al., 2002).

Leadership is defined by some experts such as Bennis (1989) who stated that leadership is a process to influence employees to act and behave in certain ways as expected by a leader. Fiedler (1967) defined leadership as an attempt to direct or coordinate certain tasks for members of a group. Merton (1969) mentioned that leadership is a process to influence certain group of people in an organized way in order to achieve certain goals. Leadership can also be seen within the context of a group or organization as mentioned (Bennis, 1989), Fiedler (1967) and Merton (1969) that leadership is a process to influence other people either individually or as a group to be directed and organized in certain ways in order to achieve certain goals. Stogdill (Dunford, 1995) mentioned some physical characteristics and mental characteristics of a leader including; age, appearance, fluency in speaking, smartness, energetic manner, dominance, having high confidence, extroverted, high motivation and competence in implementing effective leadership. Lewin, Lippitt and White (1939) in the 1930s conducted a study on the level of freedom which resulted to new terminologies on leadership such as autocratic, democratic and laissez-faire. Transformational leadership is an expansion of the transactional leadership in which the transformational leadership is not only limited to exchanges and agreement. Hoy and Miskel (2008) stated that transformational leaders should be proactively enhancing people's awareness on the importance of inspirational collective interests and leaders are expected to always provide helps for employees to achieve maximum results. Furthermore, Gibson et al. (2000) explained that transactional leadership is able to adjust to various goals, directions and missions for practical reasons. On the other hand, transformational leadership is also powerful in creating major changes in an individual as well as in an organization regarding to the procedure in doing jobs and human resources management to achieve certain missions. Hillebrandt (2000) highlighted that good leadership is necessary to implement in any sector from the industrial sector up to construction projects. Technically, construction jobs are quite complex since the jobs demand a good combination of various specific skills in which lots of people with different background from different organizations and culture. Therefore, it is necessary to have a leader who is able to collaborate those aspects to achieve the goals as planned.

Communication is a process that connects individuals and groups within an organization or society by creating, sending and using information to make coordination among members of an organization (Ruben and Stewart, 2006). Communication is a process in which a peson is interactively creating, maintaining and managing certain meaningful message (Conrad and Poole, 2005). Communication is also an interaction maintained among individuals or groups in which information is delivered to receivers to be understood. In addition, communication is also able to create, maintain and organize certain messages within a society. Organizational communication is an exchange of information within a group which members share interdependent relationship to face certain situations (Goldhaber, 1986). Communication is an activity that connects individuals or groups of people in an organization (Lubis, 2008). Basically, organizational communication is a communication maintained in an organization by exchanging messages among individuals or groups in order to grow similar perspective in performing their jobs. Within construction job context, Yang et al. (2007), Watson and Gallagher (2005) effective communication is quite important to maintain good teamwork and coordination among workers and it can also be used to motivate workers to perform their jobs well as stated in the contract. Failure of construction industries is strongly influenced by ineffective communication (Wikforss and Alexander, 
2007). One of factors that trigger ineffective communication is the fact that construction projects are temporary projects with time limitation.

Kreitner and Kinicki (2001) defined job satisfaction as an effectiveness or emotional responses toward various aspects of a job. Meanwhile, Davis and Newstrom (2000) described job satisfaction as a set of employees' personal feelings related to how enjoyable the jobs seem to them. According to Robbins (2001), job satisfaction refers to the general behavior shown by a person about her/his job that reflects the appropriateness between what is earned and what is believed to be earned. Job satisfaction is a key factor in doing construction jobs since it is the connector between the managerial staffs and employees which is important for project supervisors to determine the wages for employees (Uwakweh, 2005). Measurement on job satisfaction of construction sector adopts the theory of job satisfaction in which job satisfaction is seen as the suitability between what is expected and what is experienced while performing certain jobs (Locke, 1969). Job satisfaction also refers to the positive or negative feelings of an employee toward his/her job (Odom et al., 1990).

\section{CONCEPTUAL FRAMEWORK OF THE STUDY}

Leadership is a competence to influence a group of people to achieve certain predetermined goals (Robbins and Judge, 2009). Leadership is also a skill owned by a leader to inspire and motivate members of an organization to achieve organizational goals. Meanwhile, Elenkov (2002) and Vecchio et al. (2010) stated that leadership has certain influences toward job performance and job satisfaction, Kincaid and Schramm (1987) explained that communication is a process of sharing information among people to obtain other information. Organizational communication reflects the effective communicative behavior in an organization (Yu and Miller, 2003).

Job satisfaction refers to a positive feeling over the evaluation of the jobs that have been done (Robbins and Judge, 2009). Job satisfaction is able to improve one's job performance which later will also enhance the organizational performance. Communication also has a significant influence toward the job satisfaction since good communication improves employees' job satisfaction. Vinnicombe (1984) showed that effective communication maintained within an organization may stimulate improvement on employees' job satisfaction.

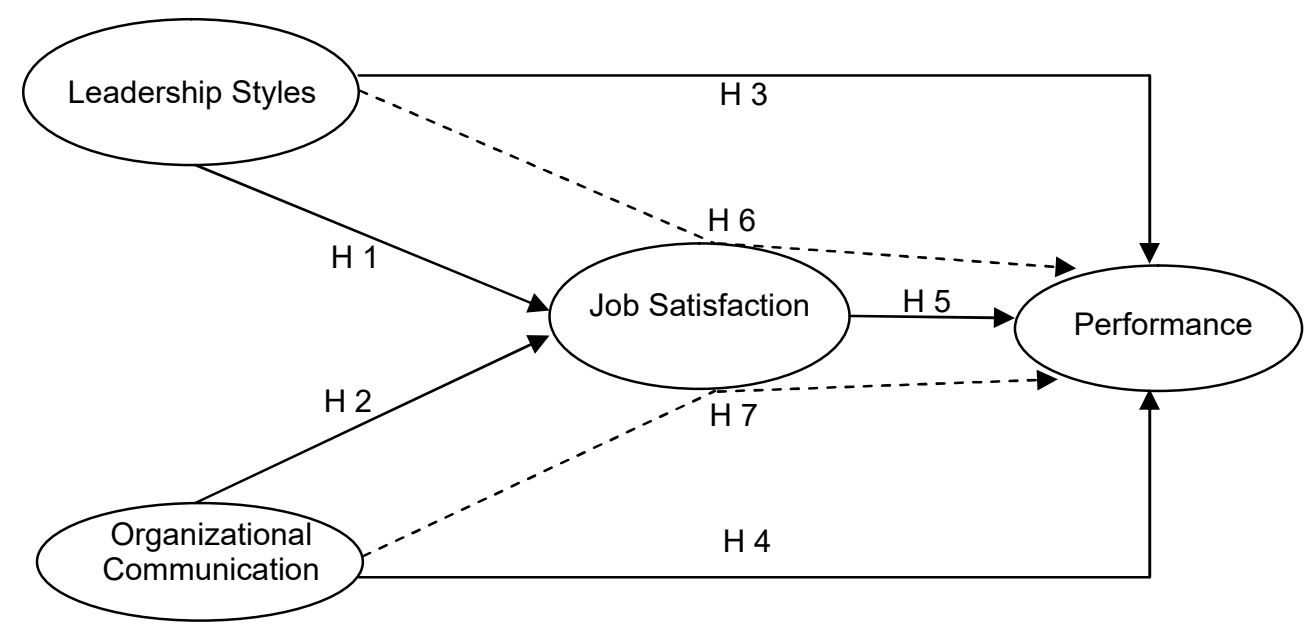

Figure 1 - The Conceptual Framework

Leadership styles influence employees' job satisfaction. Leadership is seen as way to run the function of a leadership and how a leader behave toward the employes (Mullins, 2000). Leadership has a function to guide the employees to behave in certain ways to achieve job satisfaction and organizational commitments. Hence, jobs will be finished optimally (Lok and Crawford, 2004; Chang and Lee, 2007). Leadership styles and 
organizational culture have significant influence toward employees' job satisfaction (Lund, 2003; Yiing and Ahmad, 2009). Therefore, the first hypothesis of the study was formulated as follows.

$\mathrm{H}_{1}$ : Suitable leadership style improves employees' job satisfaction.

Organizational communication influences employees' job satisfaction. Communication includes any information transfer technique from peoples' mind and behavior shown to other people. Communication represents people's mind which can be used to influence others' minds (Moghimi and Firozabad, 2013). Anderson and Martin (1995) stated that even though internal communication provides members with important information related to the organization and the jobs, individuals usually demand more information and do communication to fulfill interpersonal needs which make them feel that they are part of the organization. Farahbod et al. (2013) mentioned that communication is able to improve employees' satisfaction. Effective internal communication stimulates improvement on job satisfaction and provides the organization with better competitiveness and competence (Gray and Laidlaw, 2004). Based on this reason, the hypothesis of this study was formulated as follows.

$\mathrm{H}_{2}$ : Better organizational communication improves employees' job satisfaction.

Leadership styles influence job performance. Leadership is the most important factor within the management of a construction company since leadership is beyond just managing the project but it is also an art to influence others' behaviors to achieve certain goals (Bhangale and Devalkar, 2013). Leadership and team effectiveness are closely correlated to the effectiveness of a construction company for suitable leadership is able to support the success of the construction project (Naoum, 2001). Yang et al. (2011) mentioned that the strength of the influence of leadership style toward the success of the project depends on the characteristic of the industrial sectors and types of the projects. Leadership plays an important role in the construction companies to improve better performance. Therefore, the hypothesis of the study was formulated as follows.

$\mathrm{H}_{3}$ : Leadership styles improve job performance of construction companies.

Organizational communication influences job performance. Communication and information hold important roles for the team effectiveness (Yang et al. 2011) since communication distributes effective information for the members of the team. Haas and Hansen (2007) explained that within a complex condition and interrelated tasks, communication and information sharing among members of a team is very much crucial to maintain the whole organizational productivity of a company. Communication is a two-way interaction which balances the organizational targets and stakeholders' expectations to provide excellent intern and extern organizational effectiveness (Collier et al., 2004). Effective communication maintained in a project solves problems in a team which also shows that communication is able to improve job performance. Hence, the hypothesis of this study was formulated as follows. company.

$\mathrm{H}_{4}$ : Better organizational communication improves job performance of a construction

Employees' job satisfaction influences job performance. Job satisfaction is one's evaluation toward fairness in doing certain job, making the satisfaction does not only support better performance, but it also get them feel high organizational citizenship behavior (Organ, 1988). A newest meta-analysis obtained from 16 studies show that performance and behavior have significant influence on job satisfaction (Riketta, 2008). Frino (2010) stated that job satisfaction has certain influences toward the job performance of professional salesmen. Yang (2012) found that job satisfaction positively influenced the job performance. Meanwhile, in a study on the characteristics of personality and the correlation between job achievement and job satisfaction showed that job satisfaction has certain influence toward job performance. Based on those statements and the results of previous studies, the hypothesis of this study was formulated as follows.

$\mathrm{H}_{5}$ : Higher job satisfaction improves job performance.

Job satisfaction is a mediating variable between the influence of leadership styles toward job performance. Results of the research conducted by Voon et al. (2011), Braun et 
al. (2013), Sabir et al. (2012) indicate that leadership styles influence job satisfaction. Meanwhile, a research that attempted at connecting the job satisfaction and job performance were conducted by Riketta (2008), Perera at al. (2014), Yang (2012) which results show that job satisfaction influence job performance. The results of those previous studies showed that job satisfaction might be the mediating variable between leadership styles and job performance. Keller (2006) stated that leadership is able to influence the teamwork with the support of good competence, intern satisfaction and organizational formalization which show that leadership might influence job performance through the role of other variable. Therefore, the hypothesis of this study was formulated as follows.

$\mathrm{H}_{6}$ : Employees' job satisfaction is a mediating variable of the influence of leadership styles on job performance.

Job satisfaction is a mediating variable between the influence of organizational communication toward job performance. Job satisfaction is one's evaluation toward fairness in doing certain job, making the satisfaction does not only support better performance, but it also get them feel high organizational citizenship behavior (Organ, 1988). Social satisfaction and instrumental satisfaction influence the performance of a team (Nerkar et al., 1996). Job satisfaction shares a positive influence toward employees' performance (Van Scotter, 2000). Job satisfaction positively influences job performance (Yang, 2012). Reviews on the relationship between job satisfaction and job performance show that employees' job satisfaction influences job performance. Earley and Mosakowski (2000) stated that communication builds up strong organizational culture that improves job performance and team effectiveness, showing that communication enhances job performance through organizational culture. Effective intern communication stimulates higher job satisfaction which also support better competitiveness and competences of an organization (Gray and Laidlaw, 2004). Therefore, the hypothesis of this study was formulated as follows.

$\mathrm{H}_{7}$ : Job satisfaction is a mediating variable between the influence of organizational communication toward job performance.

\section{METHODS OF RESEARCH}

This study employed a positivistic approach which was used to test the theory, describe the experiences and observation and to do measurement and tests (O'Leary, 2000). Meanwhile, Hirschheim (1985) stated that positivistic approach is used to explain and predict social domain by seeking for causal relationship among the elements. This study is a survey research conducted by analyzing the information obtained from individual samples to be drawn into conclusions that reflects bigger population (Kelley et al., 2003). Research setting in which this study was conducted reflects the scope of the study. This study was conducted at PT. Mega Persada Indonesia, PT. Jaga Citra Inti and PT. Jaya Teknik Indonesia which are reputable mechanical and electrical construction companies in Indonesia. The determination of population was the first step to choose the respondents. After the population had been determined, samples were chosen to reflect the population. The population of this study are all of senior staffs under project leaders involving 151 respondents that consisted of 71 respondents from PT. Mega Persada Indonesia, 40 respondents from PT. Jaya Teknik Indonesia, and 151 respondents from PT. Jaga Citra Inti. Quota sampling technique was used to determine the samples which allowed the researcher to take certain employees from certain level who understood the whole job of the companies including the financial aspect, quality, and time management. This study employed the Generalized Structured Component Analysis (GSCA) to analyze the data.

\section{RESULTS AND DISCUSSION}

The result of the data analysis shows that the coefficient value of leadership styles (X1) toward job satisfaction (Y1) was found at 0.002 with a critical ratio of 0.02 . This result shows that the leadership styles (X1) does not have any significant influence toward job satisfaction (Y1). Therefore, hypothesis 1 which states that suitable leadership styles improve 
employees' job satisfaction is rejected. Leadership styles of project managers do not support job satisfaction. The strongest indicator that builds up leadership styles is the supportive leadership in which project managers should actively motivate the employees. Project managers of this study were not yet able to optimally implement the supportive leadership. This result goes contradictory to the result of the study conducted by Voon et al. (2011) which stated that leadership styles consisting of transformational and transactional leadership had significant influence toward job satisfaction. Leadership styles consists of directive leadership, participative leadership and supportive leadership influenced the job satisfaction. The gap of these studies indicates that different leadership styles give different results. Besides, different research objects also give different results. Different job environment and different employees' characteristics also give different results.

The coefficient value of the organizational communication and employees' job satisfaction was found at 0.576 with critical ratio of $6.65^{*}$. Those values show that organizational communication influence employees' job satisfaction. Based on the result of the data analysis, the hypothesis 2 is accepted meaning that the higher the organizational communication, the higher the job satisfaction. The result of the analysis also show that organizational communication done by project managers have been able to give positive influence toward employees' job satisfaction. Basically, organizational communication is a process of building good relationship and teamwork among members of an organization. Good organizational communication is able to build favorable relationship and good teamwork that motivate the employees to do their job well and feel satisfied in performing their jobs. It is stated by Trombetta and Rogers (1988) that well-maintained communication in an organization is able to stimulate job satisfactory among employees. Construction jobs require a simultaneous process from planning, designing, financial management, process management up to the finishing step which demand good quality and systematic organizational communication to deliver messages across members. Communication within the project management has a key role to maintain good relationship among members and to stimulate the good understanding and teamwork (Uher and Devenport, 2009). Communication within a construction project also holds a strategic role to build conducive work situation that lets everyone work based on the predetermined plan. Good communication that builds conducive work environment also creates comfortable situation for the employees to work and to feel satisfied with their jobs.

The coefficient value of the influence of leadership styles toward the job performance of construction companies was found at 0.003 with a critical ratio of 0.38 . This result shows that leadership styles do not have any significant influence toward the job performance of construction companies. Based on the result of the data analysis, the hypothesis 3 which states that suitable leadership styles will be able to improve the job performance is rejected. This study shows that leadership styles which consists of directive leadership, supportive leadership, participative leadership and target-oriented leadership do not bring any influence toward the job performance since construction projects run well without those aspects. Limsila and Ogunlana (2008) found a correlation between leadership styles and job achievement. There is a correlation between leadership styles and job performance. Those results are different from the result of this study which might be caused by the use of different concepts of leadership styles and different research settings.

The coefficient value of the relationship between organizational communication toward the job performance of construction companies was found at 0.295 with critical ration of $2.85^{*}$. This result shows that there is a significant influence of the organizational communication toward job performance. Based on this result, the hypothesis 5 which states that better organizational communication implemented by project managers is able to give significant influence to the job performance is accepted. This result indicates that better organizational communication stimulates better job performance. The item of organizational communication that has the strongest influence is the communication with the employees, in which leaders are expected to guide the employees to do their job well. The result of this study supports the result of the previous study conducted by Yang et al. (2007) that good coordination is able to build good teamwork which stimulates better job performance. Watson 
and Gallagher (2005) stated that basically, construction job requires good communication for good coordination, changes and motivation to achieve the targets of the project. Organizational communication has a positive relationship with organizational commitment and job performance.

The coefficient value of the relationship between job satisfaction toward job performance of construction companies was found at 0.425 with critical ratio of $5.69^{*}$. This result shows that job satisfaction has a significant influence toward job performance of construction companies. Based on this result, the hypothesis 5 is accepted. Hence, job satisfaction felt by project employees is able to stimulate better job performance. The most frequent item of job satisfaction perceived by employees is the fairness, in which employees feel that they belong to the team and are fairly treated. This result supports the result of previous study conducted by Nerkar et al. (1996) that job satisfaction socially and instrumentally influences job performance. Yang et al. (2012) mentioned that job satisfaction supports job performance. Previous studies were not conducted to industrial companies yet the results of those studies are similar. This study shows that job satisfaction influences job performance.

The result of Sobel (1982) test shows p-value of the influence of leadership styles toward job satisfaction was found at 0.981005 . The $p$-value of 0.981005 is greater than 0.05 , meaning that job satisfaction is not the mediating variable of the influence of leadership styles toward job performance of the construction companies. Therefore, hypothesis 6 which states that job satisfaction is a mediating variable of the leadership styles toward job performance is rejected. Therefore, leadership styles that consist of directive leadership, supportive leadership, participatory leadership and target-oriented leadership are not yet able to meet the expectation of the employees and are not yet able to stimulate better job satisfaction. Leadership styles implemented by project managers in the form of directive leadership, supportive leadership, participatory leadership and target-oriented leadership are not suitable to be implemented in managing construction jobs and are not yet able to give positive influence toward job satisfaction and job performance. The result of this study does not support the one found by Barbuto (2005) who confirmed that motivation is a mediating variable between leadership styles and job performance. Whilst, in this study, job satisfaction was set as the mediating variable, yet the result of the data analysis shows that job satisfaction does not actively work as the mediating variable of the leadership styles in improving better job performance.

The result of Sobel (1982) test administered to find the influence of organizational communication toward job satisfaction and the test on the correlation path between job satisfaction toward job performance showed p-value of 0.000017 which is lesser than 0.05 . Hence, job satisfaction is confirmed as the mediating variable of the influence of organizational communication toward the job performance of construction companies. Based on those results, the hypothesis 7 which states that employees' job satisfaction is a mediating variable of the influence of organizational communication toward job performance is accepted. The strongest item of the organizational communication which influences the performance is the supervision communication which refers to the information that is passed to the employees that helps them doing their jobs well. The delivery of information that lets employees do their job well also creates favorable work environment and prevents employees from making mistakes or errors. Good job done by the employees also gives them comfortable feeling that leads to job satisfaction toward their own work. Good relationship among employees in an organization also stimulates job satisfaction and better commitment (Muller and Turner, 2009). Ducker (1970) stated that good communication maintained among employees avoids problems and supports the success of the project. Bass (1985) explained that job satisfaction strongly and consistently influences job performance. Based on the opinion stated by Muller and Turner (2009), Ducker (1970) and Bass (1985) show that theoretically, communication gives both direct and indirect influences toward job performance. The result of this study also shows that organizational communication influences job satisfaction and job performance. 


\section{CONCLUSION}

Based on the Path Goal Theory, leadership styles which have been implemented by project managers do not have any influence toward the job performance due to different characteristics of the respondents. This study involved senior staffs who are experienced in doing construction jobs for around 6-20 years and they have good knowledge on the quality performance, time allocation and funding of the companies. Therefore, leadership styles consisting of directive leadership, supportive leadership, participatory leadership and targetoriented leadership was not strong enough to stimulate better job satisfaction and better job performance.

Based on the Path Goal Theory, leadership styles do not have any influence on employees' job satisfaction because in this research, job satisfaction felt by the experienced employees has more influence on transactional aspects such as bonus, reward, prosperity supplement, and promotion since transactional aspects are more concrete. Thus, it is necessary to conduct further research on the transactional leadership style.

Organizational communication which have been implemented by project managers have been confirmed to have positive influence on the improvement of the job performance. Organizational communication used in this study refers to individual feedback, supervision communication, vertical communication, horizontal communication, the quality of communication media, communication climate and reporting.

Job satisfaction appears as a mediating variable between the influence of organizational communication and the job performance. The result of this study shows that job satisfaction directly and indirectly influences job performance. Job satisfaction item that strongly creates extern satisfaction is the satisfaction that appears out of the policies and treatments given by the companies. Job satisfaction felt by employees drives the employees to do their jobs well and to produce better job performance.

Employees' job satisfaction does not appear as the mediating variable on the influence of leadership styles toward job performance because the result of this study does not indicate the existence of any influence of job satisfaction on job performance. Therefore, job satisfaction is not the mediating variable between leadership styles and job performance.

On the other hand, job satisfaction appears as the mediating variable between the influence of organizational communication toward job performance. Job satisfaction becomes the mediating variable because organizational communication performed in the companies has been able to drive the employees to do better jobs. This well-maintained organizational communication has been able to stimulate job satisfaction which later also stimulates better job performance.

\section{SUGGESTIONS}

Project managers are suggested to always improve their leadership capacity to give strong influence on job satisfaction and job performance. Organizational communication implemented by project managers should also be improved especially the reporting step. Project managers should also be equipped with adequate skill in writing project report which contains rich information for the companies for the anticipation of future problems. It is also necessary to improve job performance especially the time efficiency because construction projects usually could not meet the deadline. Construction companies are also expected to organize feasible schedule of the project timeline, human resources, facilities, and possible problems that might appear in the project. The three construction companies that participated in this study are also suggested to take benefits from the result of this dissertation by implementing leadership style which focuses on the betterment of organizational communication and job satisfaction that will also give positive influences on the project performance, funding, quality, time management and the safety aspects of the construction projects. 


\section{REFERENCES}

1. Anderson, C.M. and Martin, M.M. (1995). The Effects of Communication Motives, Interaction Involvement, and Loneliness on Satisfaction. Small Group Research, 26(1).

2. Barbuto, J.E. (2005). Motivation and transactional, charismatic and transformational leadership: a test of antecedents. Journal Leadership Organizational Study, 11(4): 26-40.

3. Bass, B.M. (1985). Leadership and Performance Beyond Expectations. The Free Press, New York.

4. Bennis, W.G. (1989). Why leaders can't lead: The unconscious conspiracy continues. Jossey-Bass, San Francisco.

5. Bhangale P.P. and Devalkar, R. (2013). Study the Importance of Leadership in Construction Projects. International Journal of Latest Trends in Engineering and Technology (IJLTET), 2(3): 312 - 318.

6. Bjeirmi, B., Begg, P. and Scott, J. (2007). Partnering issues: the evaluation of local authority adoption of partnering in Scotland. Proceedings: CME 25 Conference. Reading, 16-18 July.

7. Braun, S., Claudia, P., Silke, W. and Dieter, F. (2013). Transformational leadership, job satisfaction, and team performance: A multilevel mediation model of trust. The Leadership Quarterly, 24: 270-283.

8. Chang, S. C. and Lee, M. S. (2007). A study on relationship among leadership, organizational culture, the operation of learning organization and employees' job satisfaction. The Learning Organization, 14(2): 155 - 185.

9. Collier, P.M., Edwards, J.S. and Duncan, S. (2004). Communicating knowledge about police Performance. International Journal of Productivity and Performance Management, 53(5): $458-467$.

10. Conrad, C. and Poole, M.S. (2005). Strategic Organizational Communication in a Global Economy. 6th Eds. Thomson Wadsworth, Belmont, CA.

11. Davis, K. and Newstrom. (2000). Perilaku Dalam Organisasi. 7th Eds. Penerbit Erlangga, Jakarta.

12. Ducker, S. (1970). Teaching listening: Recently Developed Programs and Materials. Training and Development Journal, 24(5): 11.

13. Dunford, R.W. (1995). Organisational Behaviour: An Organisational Analysis Perspective. Addison-Wesley Publishing Company, Sydney.

14. Earley, P.C. and Mosakowski, E. (2000). Creating hybrid team cultures: an empirical test of trans national team functioning. Academy of Management Journal, 43(1): 26-49.

15. Elenkov, D.S. (2002). Effects of leadership on organizational performance in Russian companie. Journal of Business Research, 55: 467-480.

16. Farahbod, F. et al. Impact of Organizational Communication in Job Satisfaction and Organizational Commitment (Case Study Maskan Bank Guilan). Interdisciplinary Journal Contemporary Research in Business, 5(4): 419 - 430.

17. Fiedler, F.E. (1967). A Theory of Leaderships Effectiveness. Mc Graw-Hill Book Company, New York.

18. Frino, M.G. (2010). SelfEfficacy and Job Satisfaction as Predictors of Successful Performance of Sales Profesionals in Business-to-Business Sales Organizations. Unpublished Dissertation. Human Resource Development, Barry University.

19. Gibson, J.L., Ivancevich, J.M. and Donnelly, Jr. J.H. (2000). Organizations: Behaviour, Structure and Process. McGraw-Hill Companies Inc., Boston.

20. Goldhaber, G.M. (1986). Organizational Communication. Brown Publisher, lowa Wm.

21. Gray, J. and Laidlaw, H. (2004). Improving the Measurement of Communication Satisfaction. Management Communication Quarterly, 17(3): 425 - 448.

22. Haas, M.R. and Hansen, M.T. (2007). Different knowledge, different benefits: Toward a productivity perspective on knowledge sharing in organizations. Strategic Management Journal, 28(11): 1133.

23. Hillebrandt, P.M. (2000). Economic Theory and the Construction Industry. 3rd Edition. Macmillan, Basingstoke. 
24. Hirschheim, R.A. (1985). User Experience With An Assessment of Participative Systems Design. MIS Quarterly, 9(4): 295-309.

25. Hoy, W.K. and Miskel, C.G. (2008). Education Administration Theory, Research, and Practice. Mc-Graw-Hill Co., Singapura.

26. Kincaid, D.L. and Schramm. W. (1987). Asas-asas komunikasi antar manusia. Jakarta: Lembaga Penelitian, Pendidikan dan Penerangan Ekonomi dan Sosial (LP3ES) bekerjasama dengan East-West Communication Institute (EWCI), Hawaii.

27. Keller, R.T. (2006). Transformational leadership, initiating structure, and substitutes for leadership: a longitudinal study of research and development project team performance. Journal of applied psychology, 91(1).

28. Kelley, K., Belinda, C., Vivienne, B. and John, S. (2003). Methodology Matters: Good practice in the conduct and reporting of survey research. International Journal for Quality in Health Care, 15(3): 261-266.

29. Kerzner, H. (2001). Project Management: A System to Planning, Scheduling and Controlling. 7th Edition, John Wiley and Sons.

30. Kreitner, R. and Kinicki, A. (2001). Organizational Behavior. 5th Edition. Irwin McGrawHill.

31. Landy, F.J. (1989). Psychology of Work Behaviour. Brooks/Cole Publishing Company, California.

32. Lehtonen, T.W. (2001). Performance measurement in construction logistics, International Journal of Production Economics, 69: 107-116.

33. Lewin, K., Lippit, R. and White, R.K. (1939). Pattern of Aggressive behaviour in Experimentally created "Social Climates". Journal of Social Psychology, 10.

34. Limsila, K. and Ogunlana, S. O. (2008). Performance and leadership outcome correlates of leadership styles and subordinate commitment. Engineering, construction and architectural management, 15(2): 164-184.

35. Locke, E.A. (1969). The Natural and Causes of Job Satisfaction, Handbook of Industrial and Arganizational Psychology. Rand Mc Nally, Chicago.

36. Lok, P. and Crawford, J. (2004). The effect of organisational culture and leadership style on job satisfaction and organisational commitment: A cross-national comparison. Journal of Management Development, 23(4): 321 - 338.

37. Lubis Fatma Wardy. (2008). Peranan Komunikasi Dalam Organisasi. Jurnal Harmoni Sosial, II(2): $53-57$.

38. Lund, D.B. (2003). Organisational culture and job satisfaction. Journal of Business and industrial Marketing, 18(3): 219-236.

39. Marboen, A. (2014). Indonesia Mampu Dominasi Jasa Konstruksi Asean. Retrieved from http://www.antaranews.com/berita/437691.

40. Merton, R.K. (1969). The Social Nature of Leadership. American Journal of Nuns

41. Moghimi, M. and Firozabad, (2013). The Mediating Effect of Psychological Empowerment and Job Satisfaction in the Relationship between transformational leadership and organizational behaviour. Journal of Basic and Applied, 237-244.

42. Muller, R. and Turner, R. (2009). Leadership competency profiles of successful project managers. International Journal of Project Management, 28(5): 437-48.

43. Mullins L. J. (2000). Management and Organisational Behaviour. Pitrnan Publishers.

44. Naoum, S. (2001). People and organizational management in construction. Thomas Telford.

45. Nerkar, A.A., McGrath, R.G. and MacMillan, I.C. (1996). Three facets of satisfaction and their influence on the performance of innovation teams. Journal of Business Venturing, 11(3): 167-188.

46. Odom, R.Y. et al (1990). Organizational Cultures, Commitment, Satisfaction, and Cohesion. Public Productivity and Management Review, 14(2): 157-169.

47. Organ, D.W. (1988). Organizational citizenship behavior: The good soldier syndrome. Lexington Books, Lexington, MA.

48. O'leary, D. (2000). Enterprise Resource Planning Systems; Systems, Life Cycle, Electronic Commerece and Risk. Cambridge University Press, United Kingdom. 
49. Perera, G.D.N., Khatibi, A., Navaratna, N. and Chinna, K. (2014). Job satisfaction and job performance among factory employees in apparel sector. Asian Journal of Management Sciences and Education, 3(1): 96-104.

50. Riketta, M. (2008). The Causal Relation Between Job Attitudes and Performance: A Meta- Analisys of Panel Studies. Journal of Applied Psychology, 93(2): 472-481.

51. Robbins, S.P. (2001). Organizational Behavior. 9th Edition. Prentice Hall International Inc.

52. Robbins, S.P. and Judge, T.A. (2009). Organizational Behavior, 13th ed, Pearson Education, NJ.

53. Ruben, B.D. and Stewart, L.P. (2006). Communication and Human Behavior. Allyn and Bacon, United States.

54. Sabir, S.M., Javed, I.J., Ur, R.K., Ali, S.K. and Yameen, M. (2012). Impact of Corporate Ethical Values on Ethical Leadership and Employee Performance. International Journal of Business and Social Science, 3(2): $163-171$.

55. Sedarmayanti. (2007). Manajemen Sumber Daya Manusia, Cetakan Pertama, PT. Refika Aditama, Bandung.

56. Shore, M.L and Martin, H.J. (1989). Job satsifaction and organizational commitment relation to work performance and turnover intention. Journal of human relation, 42(7): 625-638.

57. Simanjuntak, P.J. (2005). Manajemen dan Evaluasi Kinerja. FE UI, Jakarta.

58. Sobel, M.E. (1982). Asymptotic confidence intervals for indirect effects in structural equation models. In S. Leinhardt (Ed.), Sociological methodology, 1982 (pp. 290-312). American Sociological Association, Washington, DC.

59. Takim, R. and Akintoye, A. (2002). Performance indicators for successful construction project performance. In: Greenwood, D (Ed.), 18th Annual ARCOM Conference, 2-4 September 2002, University of Northumbria. Association of Researchers in Construction Management, Vol. 2, pp. 545-55.

60. Thomas, S. Ng. et al (2002). A dynamic e-Reporting system for contractors performance appraisal. Advances in Engineering Software, 33: 339 - 349.

61. Trombetta, J. et al (1988). Communication climate, job satisfaction, and organizational commitment: The effects of information adequacy, communication openness, and decision participation. Management Communication Quarterly, 1: 494-514.

62. Uher, T.E. and Philip, D. (2009). Fundamentals of Building Contract Management. UNSW Press. University of New South Wales, Sydney.

63. Uwakweh, B.O. (2005). Effect of Foremen on Construction Apprentice, Journal of Construction Engineering and Management, 131(12): 1320-1327.

64. Van Scotter, J.R. (2000). Relationships of Task Performance and Contextual Performance With Turnover, Job Satisfaction, and Affective Commitment. Human Resource Management Review, 10(1): 79 - 95.

65. Vecchio, R.P., Justin, J.E. and Pearce, C.L. (2010). Empowering leadership: An examination of mediating mechanisms within a hierarchical structure. The Leadership Quarterly, 21: $530-542$.

66. Vinnicombe, S. (1984). Communications and Job Satisfaction: A Case Study of an Airline's Cabin Crew Members, Leadership and Organization Development Journal, 5(1): 2-7.

67. Voon, M.L., Lo, M.C., Ngui, K.S. and Ayob, N.B. (2011). The influence of leadership styles on employees' job satisfaction in public sector organizations in Malaysia. International Journal of Business, Management and Social Sciences, 2(1): 24-32.

68. Watson, G. and Gallagher, K. (2005). Managing for Results. 2nd ed. Chartered Institute of Personnel and Development, London.

69. Wikforss, Ö. and Alexander, L. (2007). Rethinking Communication in Construction. The Journal of Information Technology in Construction, 12: 337-346.

70. Yang, Li-Ren., Hsiu-Feng, Y. and Yu-Fu, C. (2012). A framework for assessing impacts of leadership competency on police project performance. Policing: An International Journal of Police Strategies andManagement, 35(3): 528 - 550. 
71. Yang, J., Ahuja, V. and Shankar, R. (2007). Managing Building Projects through Enchanted Communication - An ICT Based Strategy for Small and Medium Enterprises. Paper presented at the CIB World Building Congress, Cape Town, South Africa, May, pp. 2344-2357.

72. Yang, L.- R., Huang, C.-F. and Wu, K.-S. (2011). The association among project manager's leadership style, teamwork and project success. International journal of project management, 29(3): 258 - 267.

73. Yiing, L.H. and Ahmad, K.Z.B. (2009). The moderating effects of organizational culture on the relationships between leadership behaviour and organizational commitment and between organizational commitment and job satisfaction and performance. Leadership and Organization Development Journal, 30(1): 53 - 86.

74. Yu, H.C. and Miller, P. (2003). The generation gap and cultural influence: a Taiwan empirical investigation. Cross Cultural Management, 10(3): 23-41. 